\title{
Potential of platinum-resensitization by Wnt signaling modulators as treatment approach for epithelial ovarian cancer
}

\author{
Till Kaltofen ${ }^{1}\left[\right.$ Valentina Preinfalk $^{1} \cdot$ Stephanie Schwertler ${ }^{1} \cdot$ Patricia Fraungruber $^{1} \cdot$ Helene Heidegger $^{1}$. \\ Theresa Vilsmaier $^{1} \cdot$ Aurelia Vattai $^{1} \cdot$ Bastian Czogalla $^{1}$ - Doris Mayr ${ }^{2} \cdot$ Sven Mahner $^{1} \cdot$ Udo Jeschke $^{1,3} \cdot$ Fabian Trillsch $^{1}$
}

Received: 21 June 2020 / Accepted: 8 July 2020 / Published online: 17 July 2020

(c) The Author(s) 2020

\begin{abstract}
Purpose Canonical Wnt/ $\beta$-catenin pathway is one mechanism being activated in platinum-resistant epithelial ovarian cancer (EOC). Detecting potential targets for Wnt pathway modulation as a putative future therapeutic approach was the aim of this study.

Methods Biological effects of different Wnt modulators (SB216763, XAV939 and triptolide) on the EOC cell lines A2780 and its platinum-resistant clone A2780cis were investigated via multiple functional tests. Immunohistochemistry (IHC) was carried out to compare the expression levels of Wnt marker proteins ( $\beta$-catenin, snail/slug, E-cadherin) in patient specimens and to correlate them with lifetime data.

Results We could show that activated Wnt signaling of the platinum-resistant EOC cell line A2780cis can be reversed by Wnt manipulators through SB216763 or XAV939. All Wnt manipulators tested consecutively decreased cell proliferation and cell viability. Apoptosis of A2780 and A2780cis was enhanced by triptolide in a dose-dependent manner, whereas cell migration was inhibited by SB216763 and triptolide. IHC analyses elucidated significantly different expression patterns for Wnt markers in the serous subtype. Herein, higher plasmatic snail/ slug expression is associated with improved progressionfree (PFS) and overall survival (OS).

Conclusion According to the described effects on EOC biology, all three Wnt manipulators seem to have the potential to augment the impact of a platinum-based chemotherapy in EOC. This is promising as a dominance of this pathway was confirmed in serous histology.
\end{abstract}

Keywords Ovarian cancer $\cdot$ Platinum-resistance $\cdot$ Wnt $\cdot \beta$-catenin $\cdot$ Snail/ slug $\cdot$ E-cadherin

\section{Abbreviations}

AEC 3-Amino-9-ethylcarbazole

DAB 3,3'-Diaminobenzidine

MTT 3-(4,5-Dimethylthiazol-2-yl)-2,5-diphenyltetrazolium bromide

Electronic supplementary material The online version of this article (https://doi.org/10.1007/s00432-020-03317-4) contains supplementary material, which is available to authorized users.

Till Kaltofen

Till.Kaltofen@med.uni-muenchen.de

1 Department of Obstetrics and Gynecology, University Hospital, LMU Munich, Munich, Germany

2 Department of Pathology, University Hospital, LMU Munich, Munich, Germany

3 Department of Obstetrics and Gynecology, University Hospital Augsburg, Augsburg, Germany
BrdU 5-Bromo-2'-deoxyuridine

APC Adenomatous polyposis coli

CI Confidence interval

DMSO Dimethyl sulfoxide

Dsh Dishevelled

ELISA Enzyme-linked immunosorbent assay

EMT Epithelial-mesenchymal transition

EOC Epithelial ovarian cancer

FZD Frizzled

FIGO International Federation of Gynecology and Obstetrics

ICC Immunocytochemistry

IHC Immunohistochemistry

LRP Lipoprotein receptor-related protein

LEF Lymphoid enhancer factor

OC Ovarian cancer

OS Overall survival

PARP Poly ADP ribose polymerase 
PFS Progression-free survival

TCF T-cell factor

TMA Tissue microarray

Ub Biquitination

\section{Introduction}

Epithelial ovarian cancer (EOC) is the leading cause of death from gynecologic malignancies and the seventh most common cancer in women worldwide (International Agency for Research on Cancer 2020). With a relative five-year survival rate of $41 \%$ across all Federation of Gynecology and Obstetrics (FIGO) stages, survival is poor. Diagnosis is usually made in advanced FIGO stage III and IV in $75 \%$ of the patients (Jayson et al. 2014). In case of relapse, EOC will develop platinum-resistance over time and is driven by a range of heterogeneous primary and acquired mechanisms in different signaling cascades (Freimund et al. 2018; Rabik and Dolan 2007).

One of them is considered to be the canonical Wnt/ $\beta$-catenin pathway (Fig. 1) (Barghout et al. 2015; Nagaraj et al. 2015), which is essential for the development and integrity of all multicellular organisms (Wiese et al. 2018) but dysregulation of the pathway has the potential to promote various diseases including EOC (Arend et al. 2013; Nusse and Clevers 2017; Shang et al. 2017). Except for endometrioid ovarian cancer (OC), mutations in canonical Wnt signaling in EOC are rarely seen (Kim et al. 2008),

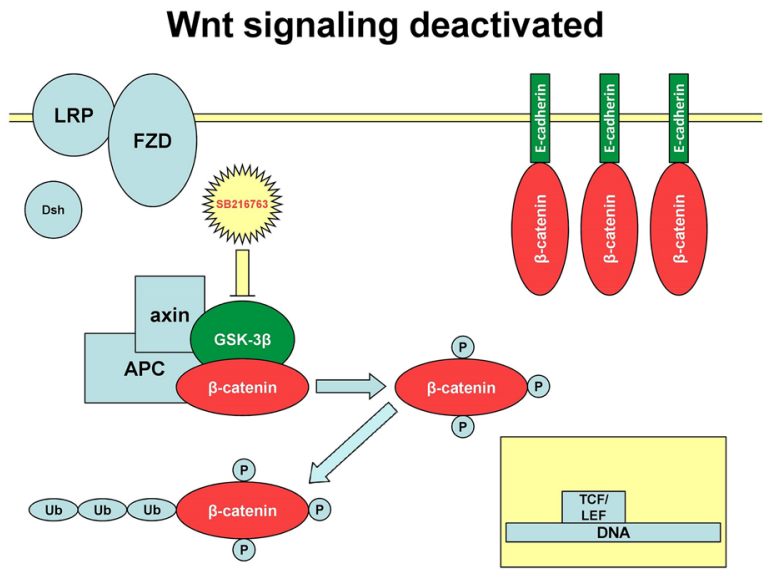

Fig. 1 Canonical Wnt signaling pathway: In absence of Wnt ligand (left), the destruction complex, consisting of GSK-3 $\beta$, adenomatous polyposis coli $(A P C)$ and axin, hyperphosphorylates $\beta$-catenin, which marks it for ubiquitination $(U b)$ and proteasomal degradation. Binding of Wnt ligand (right) to a frizzled $(F Z D) /$ lipoprotein receptorrelated protein $(L R P)$ receptor complex leads to the phosphorylation of dishevelled (Dsh) inactivating GSK-3 $\beta$ and preventing the phosphorylation of $\beta$-catenin. Non-phosphorylated $\beta$-catenin shifts into the nucleus and forms a complex with T-cell factor (TCF)/lymphoid enhancer factor $(L E F)$ activating transcription of Wnt target genes. so that in contrast a general activation of the cascade has been considered to promote tumor progression (Dubeau 2008; Gatcliffe et al. 2008). However, conflicting results indicate a possible inhibitory role for tumor progression from time to time (Bodnar et al. 2014; Seagle et al. 2016).

It has been described that inhibition of canonical Wnt signaling can re-sensitize platinum-resistant EOC cells to platinum, which, therefore, represents a promising target for therapeutic approaches. The general knockdown of $\beta$-catenin, a key regulator in canonical Wnt signaling being located in the nucleus, reinduced chemosensitivity to platinum in cisplatin-resistant OC cells in vitro (Nagaraj et al. 2015). Additional, inhibitors of the Wnt signaling cascade exhibited potential to re-sensitize EOC cells to platinum: iCG-001/ PRI-724 (Nagaraj et al. 2015), CCT036477 (Barghout et al. 2015), WNT974 (Boone et al. 2016) or triptolide (Rivard et al. 2014; Westfall et al. 2008). However, their effects have not been independently proven and their possible clinical implications have not been systematically followed.

Within this study, the clinical and prognostic significance of Wnt signaling markers have been investigated to elucidate and confirm specific targets for Wnt pathway modulations with consecutive therapeutic perspectives. Besides the investigation of the protein expression of Wnt markers, the Wnt modulators SB216763, XAV939 and triptolide were applied to investigate their effects on the cell biology of the EOC cell line A2780 and its platinum-resistant clone A2780cis and to test the ability for

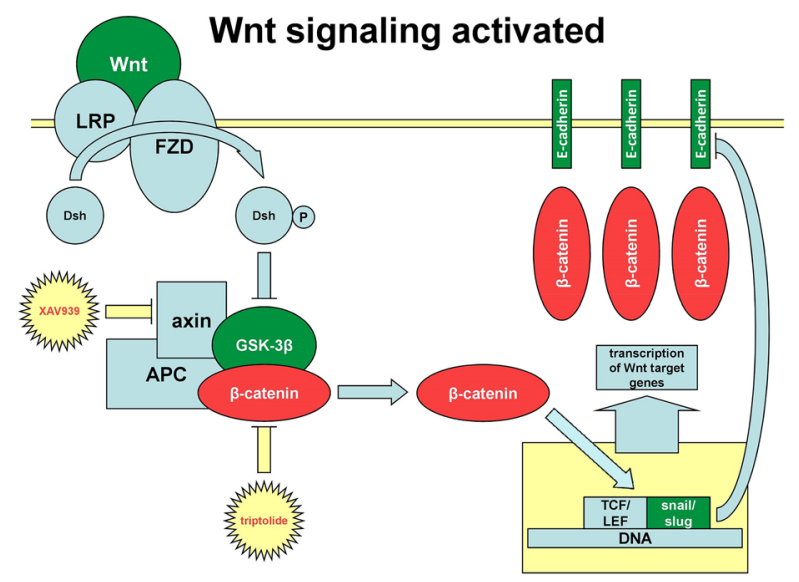

Furthermore, the expression of zinc-finger transcription factors snail and slug is upregulated. They bind to E-boxes in E-cadherins promoter region and prevent its transcription. Suppresion of E-cadherin offers more available cytoplasmic $\beta$-catenin and induces a self-driven positive feedback loop. In conclusion, by losing E-cadherin as an adhesion molecule cells undergo EMT (Arend et al. 2013; Gasior et al. 2017; Gatcliffe et al. 2008). The three inhibitors (SB216763, XAV939 triptolide) used in this study, are shown in their typical domain 
putative therapeutic approaches by increasing sensitivity to platinum.

\section{Methods}

\section{Experiments on cultured cells}

\section{Cell culture}

The EOC cell line A2780 and its platinum-resistant clone A2780cis (European Collection of Authenticated Cell Cultures, Salisbury, UK) were cultured in Roswell Park Memorial Institute 1640 medium with GlutaMAX (Gibco, Gaithersburg, MD, USA) supplemented with $10 \%$ fetal bovine serum (Biochrom, Berlin, Germany) at $37^{\circ} \mathrm{C}$ in the presence of $5 \% \mathrm{CO}_{2}$ in cell culture flasks. A2780cis cells were treated with $1 \mu \mathrm{M}$ carboplatin at each change of medium to maintain resistance. No antibiotics or antimycotics were used.

\section{Wnt modulators}

XAV939 is a small molecule inhibitor of Wnt signaling pathway. It acts through binding and inhibiting tankyrase's catalytic poly ADP ribose polymerase (PARP) domain, which usually destabilizes axin as part of the destruction complex (Chen et al. 2009; Wu et al. 2016) (Fig. 1). Wu et al. showed the resensitization to chemotherapy of colon cancer cells through XAV939 treatment (Wu et al. 2016). Furthermore, in human ovarian cancer cells, this tankyrase inhibitor was able to overcome chemoresistance driven through overexpression of long non-coding RNA ( $\mathrm{Li}$ et al. 2016).

SB216763 is an inhibitor of the glycogen synthase kinase $3 \beta$ (GSK-3 $\beta$ ) and following this, in contrast to XAV939, an activator of the Wnt/ $\beta$-catenin pathway (Naujok et al. 2014) (Fig. 1). Indeed, inhibition of the GSK-3 $\beta$ was also shown to inhibit cancer cell proliferation (Cao et al. 2006; Schulz et al. 2018), maybe attributable to several recent studies describing the GSK-3 $\beta$ as a tumor promoter besides its typical role in Wnt pathway. So far, the serine-threonine kinase has multiple functions in different regulatory mechanisms or pathways and act as a chameleon in cancer's context (Domoto et al. 2016; Patel and Woodgett 2008).

We also included triptolide, a diterpenoid triexpoxide with multiple actions in eucaryotes, in our study. Its antineoplastic impact was already shown for different solid tumors, for example, breast, bladder, stomach or ovary (Shao et al. 2014; Yang et al. 2003). Specific molecular mechanisms are still under debate. One is the degradation of $\beta$-catenin (Fig. 1) as shown in breast cancer cells (Shao et al. 2014).

\section{Cell proliferation and viability assay}

$5 \times 10^{3}$ cells/well (A2780 and A2780cis) were seeded in 96-well plates overnight and afterwards incubated with different concentrations of SB216763 (12.5 $\mu \mathrm{M}, 25 \mu \mathrm{M}$, $50 \mu \mathrm{M}, 100 \mu \mathrm{M})$ (Sigma-Aldrich, Taufkirchen, Germany), XAV939 $(6.25 \mu \mathrm{M}, 12.5 \mu \mathrm{M}, 25 \mu \mathrm{M}, 50 \mu \mathrm{M})$ (SigmaAldrich) and triptolide $(6.25 \mathrm{nM}, 12.5 \mathrm{nM}, 25 \mathrm{nM}, 50 \mathrm{nM})$ (Sigma-Aldrich).

S-phase-dependent synthesis of DNA during the cell cycle and, therefore, cellular proliferation was analyzed with thymidine analog 5-bromo-2'-deoxyuridine (BrdU) enzymelinked immunosorbent assay (ELISA) after $72 \mathrm{~h}$. Cell viability was determined using a 3-(4,5-dimethylthiazol-2-yl)2,5-diphenyltetrazolium bromide (MTT) (Sigma-Aldrich) colorimetric assay after $48 \mathrm{~h}$ and $72 \mathrm{~h}$. The procedures of both techniques were already reported by our colleagues (Geiger et al. 2016; Zhu et al. 2018).

Controls of untreated cells (for incubation with triptolide), cells treated with 2\%o (for incubation with SB216763) and 5\%o (for incubation with XAV939) dimethyl sulfoxide (DMSO) were carried out. For the evaluation the control without DMSO was set $100 \%$.

\section{M30 CytoDEATH apoptosis assay}

The M30 CytoDeath apoptosis assay is used for determination of early apoptosis. A specific epitope of cytokeratin 18 , which is presented after cleavage by caspases during apoptosis, is detected. OC cells were grown on microscope slides to subconfluency, incubated for $48 \mathrm{~h}$ in the presence of triptolide at different concentrations $(6.25 \mathrm{nM}, 12.5 \mathrm{nM}$, $25 \mathrm{nM}, 50 \mathrm{nM}$ and without as control), fixed and stored at $-20^{\circ} \mathrm{C}$. After thawing, washing and incubation with M30 CytoDEATH antibody (Alexis, San Diego, CA, USA) (Table 1) overnight immunocytochemical evaluation using ZytoChem-Plus HRP Polymer-Kit (Zytomed Systems, Berlin, Germany) and 3,3'-diaminobenzidine as chromogenic substrate (DAB) (Carl Roth, Karlsruhe, Germany) followed. Images were captured with a microscope including a digital camera system (Leica, Wetzlar, Germany).

\section{Cell death detection ELISA}

Cell death was quantified with the sandwich-enzyme-immunoassay-method of Cell Death Detection ELISA ${ }^{\text {PLUS }}$-Kit (Roche, Basel, Switzerland) according to the manufacturer's protocol. Following induced cell death, mouse monoclonal antibodies bind against cytoplasmic histone-associated DNA-fragments (mono- and oligonucleosomes). In brief, $5 \times 10^{4}$ cells/well were grown overnight in 96-well culture plates and then incubated with $6.25 \mathrm{nM}, 12.5 \mathrm{nM}, 25 \mathrm{nM}$ and $50 \mathrm{nM}$ of triptolide for $24 \mathrm{~h}$. Details on the further 
Table 1 Antibodies used in this study: Stated are only antibodies, not part of a laboratory kit

\begin{tabular}{lllll}
\hline Antigen & Antibody & Dilution & Detection system & $\begin{array}{l}\text { Chro- } \\
\text { mogenic } \\
\text { substrate }\end{array}$ \\
\hline$\beta$-catenin & Anti- $\beta$-catenin (rabbit IgG) & $1: 600$ & Vectastain Elite rabbit-IgG-Kit & AEC \\
& & $1: 300$ & ZytoChem-Plus HRP Polymer-Kit & DAB \\
E-cadherin & Anti-E-cadherin (mouse IgG) & $1: 100$ & ZytoChem-Plus HRP Polymer-Kit & DAB \\
M30 & Anti-M30 (mouse IgG) & $1: 50$ & ZytoChem-Plus HRP Polymer-Kit & DAB \\
Snail/slug & Anti-snail/slug (rabbit IgG) & $1: 800$ & ZytoChem-Plus HRP Polymer-Kit & DAB \\
\hline
\end{tabular}

procedure can be found in Geiger et al. (Geiger et al. 2016). The apoptotic index is presented as an enrichment factor, which is calculated as absorbance of sample cells divided by absorbance of control cells without triptolide (enrichment factor $=1.0$ ).

\section{Wound healing assay}

The assays were performed according to the protocol in Zhu et al. (2018). After the standardized scratching on A2780 and A2780cis monolayers, we added $100 \mu \mathrm{M}$ SB216763, $50 \mu \mathrm{M}$ XAV939 or $50 \mathrm{nM}$ triptolide. Controls were carried out in parallel to cell proliferation and viability assay. Afterwards, cell migration was documented by measuring the wounds area after 0 (wound area $=100 \%$ ), 24, 48 and $72 \mathrm{~h}$.

\section{Immunocytochemistry (ICC) to illustrate ß-catenin shift}

Subcellular localization of $\beta$-catenin while adding Wnt signaling manipulators was investigated by ICC. After A2780 and A2780cis cells grew on microscope slides to subconfluency, they were incubated with $100 \mu \mathrm{M}$ SB2 16763 or $50 \mu \mathrm{M}$ XAV939 for $72 \mathrm{~h}$. The slides were fixed putting them into phosphate-buffered saline (Gibco) for 5 min and methanol for $5 \mathrm{~min}$, followed by freezing at $-20{ }^{\circ} \mathrm{C}$. Manufactured slides were treated with anti- $\beta$-catenin IgG (Diagnostic BioSystems, Pleasanton, CA, USA) (Table 1) overnight in a moist chamber. Thereafter Vectastain Elite rabbit-IgG-Kit (Vector Laboratories, Burlingame, CA, USA) was used to detect and visualize $B$-catenin by the ABC-method with 3-amino-9-ethylcarbazole (AEC) as chromogenic substrate. Slides were counterstained with hemalaun. The images were captured using a microscope including a digital camera system (Carl Zeiss, Jena, Germany). Controls of cells treated with 2\%o (for incubation with SB216763) and 5\%o (for incubation with XAV939) DMSO were carried out.

\section{Statistical analysis of cell culture experiments}

Statistical analysis was performed with GraphPad Prism 8 (GraphPad Software, La Jolla, CA, USA). Significant differences to controls were determined by one-way ANOVA followed by Dunnett's multiple comparisons test or two-way ANOVA followed by Sidak's multiple comparisons test. A probability of $p<0.05$ was considered significant. The columns in each graph show the mean of relative values in $\%$ or as an enrichment factor. Therefore, the presentation of error bars is not applicable in our study.

\section{Experiments on human tissue samples}

\section{Patient cohort and ethics approval}

Specimens represent a cohort of 153 patients with EOC (serous $[n=109]$, endometrioid $[n=21]$, clear cell $[n=11]$, mucinous $[n=12])$ who underwent radical cytoreductive surgery in our department between 1990 and 2002. Histopathological diagnoses were established by a specialized gynecologic pathologist with staging and grading according to TNM and FIGO (WHO) classification. $75.2 \%$ of patients presented with advanced disease (FIGO IIB-IV), while only $24.8 \%$ were diagnosed in early disease (FIGO I-IIA). Except for patients in stage FIGO IA with low-grade histology, all patients received adjuvant platinum-based chemotherapy. Lifetime data (birth, primary OC diagnosis, relapse, death) from EOC patients were taken from our patient charts, the Munich Cancer Registry and aftercare calendars. Median age at primary diagnosis was 59.0 years with a $95 \%$ confidence interval (CI) of 57.0-61.0 years. 28 relapses and 101 deaths were documented. A summary of patient characteristics can be found in Table 2. Our study has been approved by the ethics committee of Ludwig Maximilian University of Munich (reference number 138/03) and was carried out in compliance with the guidelines of the Helsinki Declaration of 1964 (last revision October 2018). All participants gave their written informed consent. Samples and clinical information were anonymized for statistical workup.

\section{Tissue microarray (TMA)}

Out of representative regions of the paraffin-embedded tumor samples biopsies $0.6 \mathrm{~mm}$ in diameter were taken and arrayed into a recipient paraffin block $(30 \times 20 \times 10 \mathrm{~mm})$ using a microtissue arrayer (Beecher Instruments, Sun 
Table 2 Patient characteristics: shown are the categorization for histological subtype, grading and FIGO stage of the specimens from the cohort of 153 patients with EOC and a summary of their according lifetime data

\begin{tabular}{|c|c|c|c|c|}
\hline \multicolumn{5}{|l|}{ Histology and stage } \\
\hline & Category & & $n$ & $\%$ \\
\hline \multirow[t]{17}{*}{ Subtype and grading } & Serous & Low-grade & 24 & 15.7 \\
\hline & & High-grade & 80 & 52.3 \\
\hline & & Not classified & 5 & 3.3 \\
\hline & & Total & 109 & 71.3 \\
\hline & Endometrioid & G1 & 6 & 3.9 \\
\hline & & G2 & 5 & 3.3 \\
\hline & & G3 & 8 & 5.2 \\
\hline & & Not classified & 2 & 1.3 \\
\hline & & Total & 21 & 13.7 \\
\hline & Clear cell & G3 & 9 & 5.9 \\
\hline & & Not classified & 2 & 1.3 \\
\hline & & Total & 11 & 7.2 \\
\hline & Mucinous & G1 & 6 & 3.9 \\
\hline & & G2 & 6 & 3.9 \\
\hline & & G3 & 0 & 0.0 \\
\hline & & Not classified & 0 & 0.0 \\
\hline & & Total & 12 & 7.8 \\
\hline \multirow[t]{4}{*}{ FIGO } & I & & 35 & 22.9 \\
\hline & II & & 12 & 7.8 \\
\hline & III & & 103 & 67.3 \\
\hline & IV & & 3 & 2.0 \\
\hline \multicolumn{5}{|l|}{ Lifetime data } \\
\hline & Median (years) & & 95\% CI (years) & \\
\hline Age at diagnosis & 59.0 & & $56.0-60.0$ & \\
\hline OS & 3.6 & & $2.0-5.3$ & \\
\hline
\end{tabular}

Prairie, WI, USA). Every tumor sample was used for three biopsies, resulting in 459 TMAs in total. Afterwards, sections of $5 \mu \mathrm{m}$ were prepared and transferred to microscope slides. To determine whether there was enough representative tumor tissue left, a haematoxylin and eosin stain was done.

\section{Immunohistochemistry (IHC) for TMAs}

IHC was performed using a combination of pressure cooker heating and the ZytoChem-Plus HRP Polymer-Kit with DAB as chromogenic substrate according to a previous publication by our lab (Scholz et al. 2012). The primary antibodies in our immunohistochemical staining were anti$\beta$-catenin IgG, anti-E-cadherin IgG (Merck, Darmstadt, Germany) and anti-snail/ slug IgG (Abcam, Cambridge, UK) (Table 1). Evaluation, imaging and storing was done with an AxioScope microscope (Carl Zeiss), an AxioCam digital camera system (Carl Zeiss) and the AxioVision software
(Carl Zeiss). Immunohistochemical staining was assessed semiquantitatively, according to Remmele and Steger (Remmele and Stegner 1987) using the IHC score (mean \pm SEM). Expression of Wnt signaling markers was captured in different subcellular locations ( $\beta$-catenin: membrane and plasma, snail/ slug: plasma, E-cadherin: membrane and plasma).

\section{Statistical analysis of tissue sample experiments}

Mean values of the three representative IHC scores of every probe were calculated for further analysis. GraphPad Prism 8 was used for the comparison of immunoquantitation between histological subtypes, FIGO stages and platinum-response ( $<6$ months to primary surgery)/ -sensitive ( $\geq 6$ month to primary surgery) with Mann-Whitney- $U$ test (mean \pm SEM). Furthermore, expression-dependent differences in overall survival (OS) (median \pm SEM) and progression-free survival (PFS) (median \pm SEM) were tested by chi-square statistic of the Log-Rank test (Mantel-Cox) in Kaplan-Meier 
curves with SPSS Statistics 25 (IBM, Chicago, IL, USA). $P$-values $<0.05$ were considered to be statistically significant for further analyses.

\section{Results}

\section{In vitro experiments with cultured cell lines}

\section{Activated Wnt signaling in platinum-resistant EOC cells can be reversed by Wnt manipulators}

ICC of $\beta$-catenin was performed to indicate activation of the canonical Wnt pathway according to its nuclear localization. A significant $(p<0.05$ or $p<0.001)$ shift from $\beta$-catenin staining from the nucleus to the membrane was noted following SB216763 $(100 \mu \mathrm{M})$ and XAV939 $(50 \mu \mathrm{M})$ treatment in comparison to controls for both cell lines A2780 and A2780cis. The biggest impact presented XAV939 treatment in A2780cis, where the cell proportion with nuclear B-catenin localization decreased from $99.1 \%$ (control with 5\% DMSO) to $25.2 \%(p<0.001)$ (Fig. 2).

\section{Wnt manipulators and their effect on proliferation}

To evaluate the effect on proliferation of EOC cell lines following treatment with Wnt manipulators, BrdU assay was carried out. Since the inhibition of cell proliferation showed a dose-dependent positive correlation for triptolide but not for SB216763 or XAV939 (Supp. 1a), we compared the highest concentrations of each inhibitor against its control. Controls for triptolide without DMSO were set $100.0 \%$. After $72 \mathrm{~h}$, triptolide $(50 \mathrm{nM})$ displayed a significant $(p<0.001)$ impairment of proliferation in A2780 (17.1\%) and A2780cis $(8.9 \%)$. While XAV939 $(50 \mu \mathrm{M})$ showed no influence in both cell lines, SB216763 $(100 \mu \mathrm{M})$ also

(a)
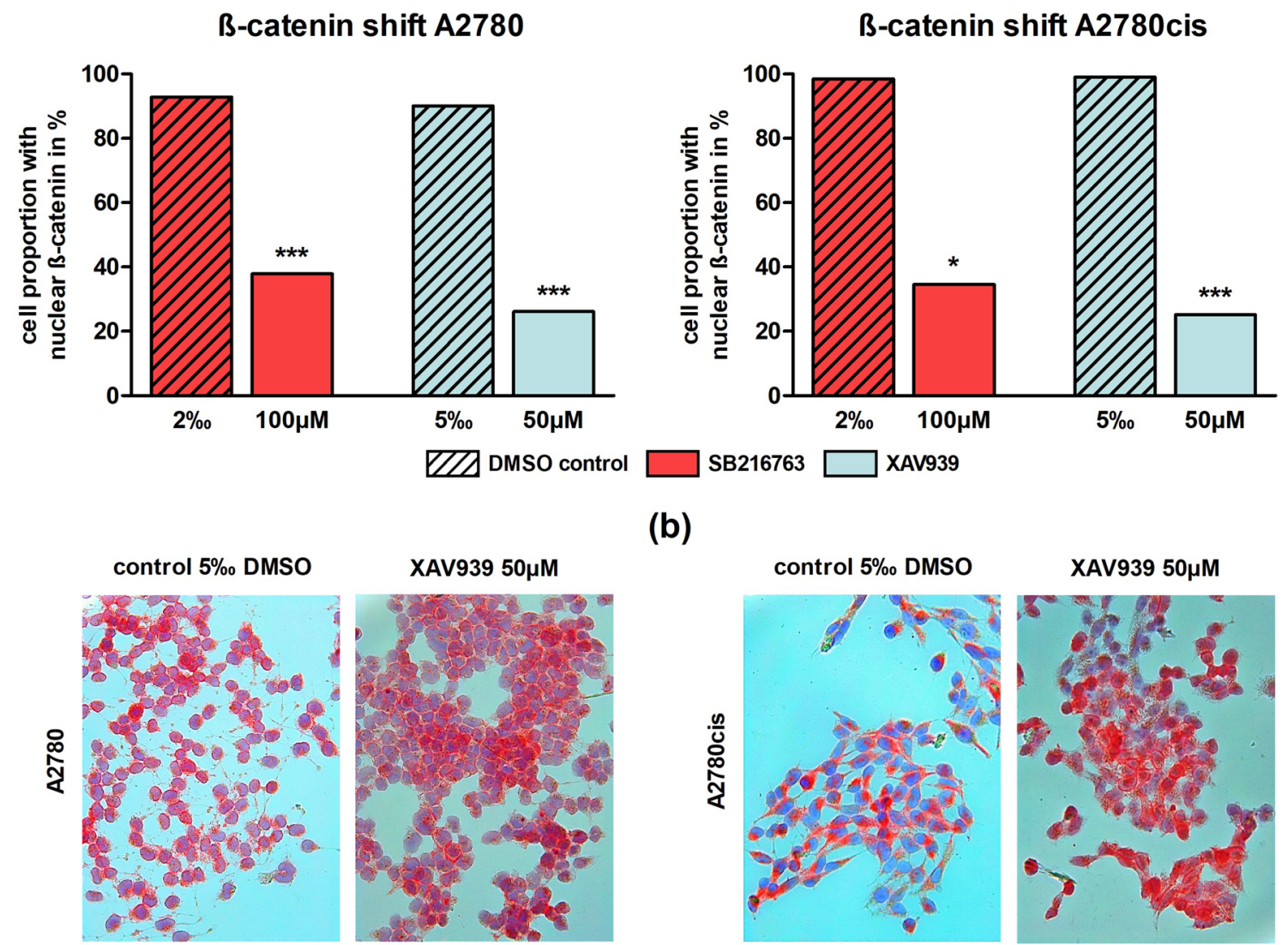

(b)

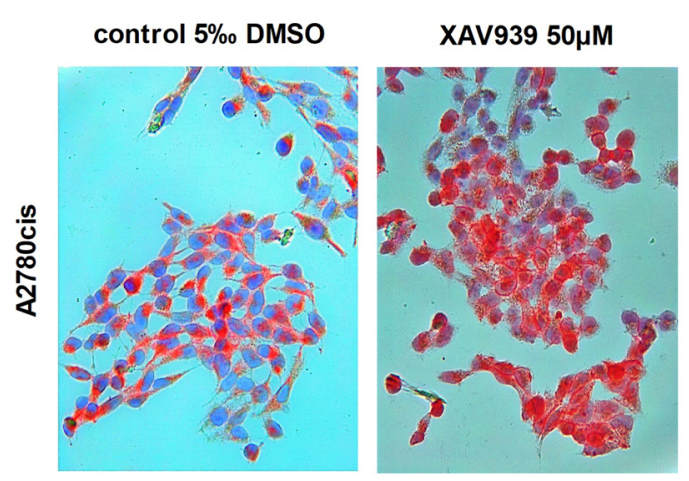

Fig. 2 B-catenin shift after treatment with different Wnt signaling manipulators in A2780 and A2780cis: a In A2780 and A2780cis the proportion of cells with nuclear localization of B-catenin was significantly decreased through the addition of $100 \mu \mathrm{M} \mathrm{SB} 216763$ or $50 \mu \mathrm{M}$ XAV939 compared to controls $\left(n=3\right.$ per column, mean, ${ }^{*} p<0.05 /$ $* * * p<0.001$ by Sidak's multiple comparisons test). b Representative

images of A2780 and A2780cis after treatment with $50 \mu \mathrm{M}$ XAV939 compared to controls with 5\%o DMSO. B-catenin is red-colored. While in controls $B$-catenin is mainly localized in the nucleus, addition of the Wnt inhibitor XAV939 leads to a shift towards the cell membrane 
(a)
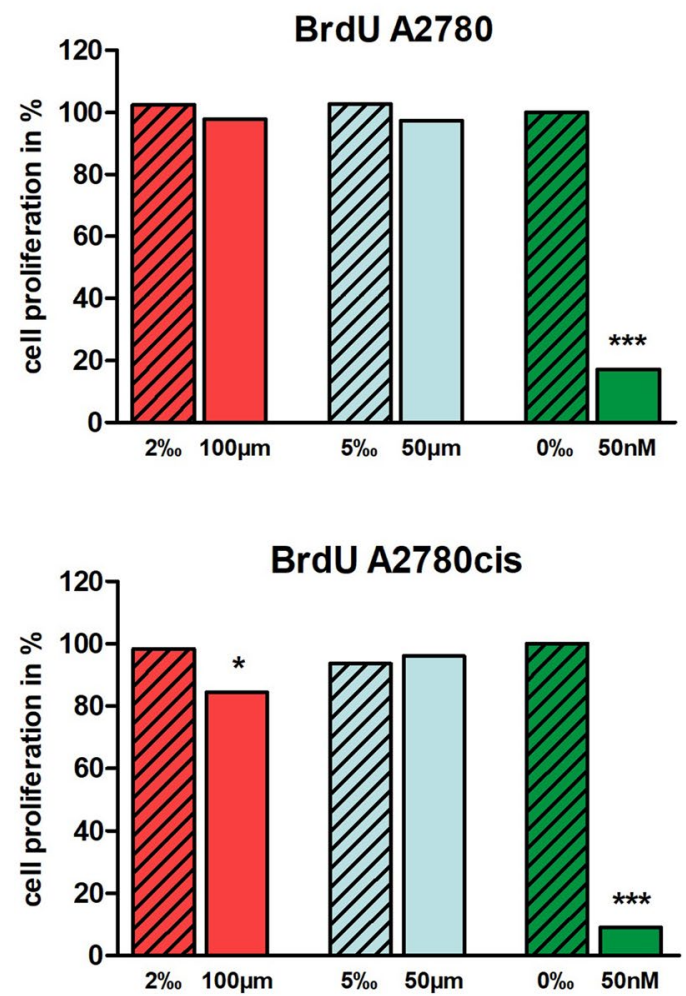

(b)
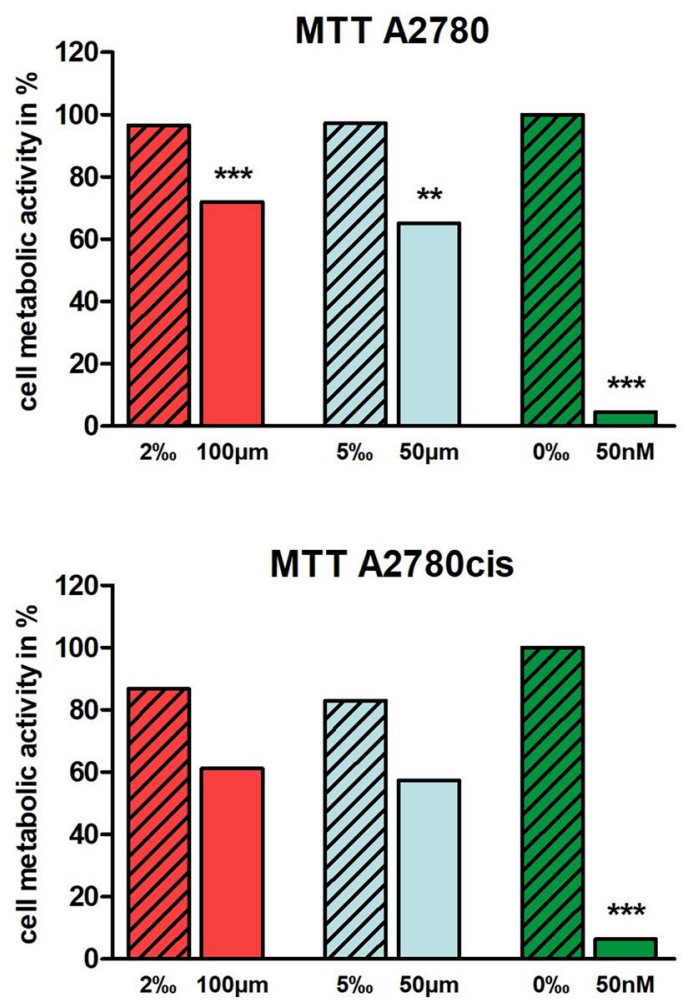

XAV939 $\square$ triptolide
ZZJ DMSO control

Fig. 3 BrdU cell proliferation and MTT cell viability assay for different Wnt signaling manipulators (100 $\mu$ M SB216763, $50 \mu \mathrm{M}$ XAV939, $50 \mathrm{nM}$ triptolide) in A2780 and A2780cis after $72 \mathrm{~h}$ : a In the BrdU assay only triptolide displayed a significant impairment of proliferation in A2780 and A2780cis, whereas SB216763 revealed a significant reduction of cell proliferation in A2780cis and XAV939 showed no influence $(n=9$ per column, mean, $* p<0.05 / * * * p<0.001$ by

significantly $(p<0.05)$ inhibited proliferation in A2780cis $(84.5 \%)$ (Fig. 3a).

\section{Impaired cell viability by Wnt manipulators}

Cell viability was examined with the MTT assay. In accordance with the BrdU assay, a dose dependence for the concentrations tested, was found only for triptolide (Supp. 1b). But in contrast to cell proliferation assay, metabolic activity decreased for all three inhibitors in platinum-sensitive (SB216763: 72.0\%, XAV939: 65.2\%, triptolide: 4.7\%) and -resistant cells (SB216763: 61.2\%, XAV939: 57.3\%, triptolide: 6.4\%) in MTT assay. Except for SB216763 and XAV939 in A2780cis, these findings were highly significant $(p<0.01$ or $p<0.001)$ at the selected concentrations of $100 \mu \mathrm{M}$ SB216763, $50 \mu \mathrm{M}$ XAV939 and $50 \mathrm{nM}$ triptolide
Dunnett's multiple comparisons test, controls with 0\% DMSO were set 100\%). b In the MTT assay all three inhibitors in platinum-sensitive and -resistant cells reduced metabolic activity with different levels of significance ( $n=9$ per column, mean, $* * p<0.01 / * * * p<0.001$ by Dunnett's multiple comparisons test, controls with $0 \%$ DMSO were set $100 \%$ )

(Fig. 3b). While triptolide already led to significantly reduced metabolic activity after $48 \mathrm{~h}$, this effect was seen for the other agents not before $72 \mathrm{~h}$.

\section{Enhanced apoptosis by triptolide in a dose-dependent manner}

To determine a Wnt inhibition induced early apoptosis, triptolide was chosen for M30 CytoDEATH apoptosis assay due to its strong impact in the previous experiments. Following $48 \mathrm{~h}$ of treatment with $6.25 \mathrm{nM}, 12.5 \mathrm{nM}, 25 \mathrm{nM}$ or $50 \mathrm{nM}$ triptolide, the percentage of apoptotic cells (M30 CytoDEATH positive) increased significantly $(\mathrm{p}<0.01$ or $p<0.001)$ in a dose-dependent manner up to $95.4 \%$ for A2780 and to $53.1 \%$ for A2780cis, respectively. Controls with 0\%o DMSO showed 100.0\% M30 CytoDEATH negative cells (Fig. 4a). 
Fig. 4 CytoDEATH apoptosis assay after $48 \mathrm{~h}$ and Cell death detection ELISA after $24 \mathrm{~h}$ for different triptolide concentrations in A2780 and A2780cis: a Apoptosis of cell lines A2780 and A2780cis was enhanced by triptolide in a dose-dependent manner. The percental rate of apoptic cells (M30 CytoDEATH positive) significantly increased in both cell lines with rising concentrations. Meanwhile, M30 CytoDEATH negative cells rapidly decreased $(n=3$ per column, mean, $* * p<0.01 / * * * p<0.001$ by Dunnett's multiple comparisons test). According to documented concentrations representative microphotographs of EOC cells with an apoptic cell proportion in intense brown after DAB treatment are added. b Incubation for $24 \mathrm{~h}$ with different triptolide concentrations revealed a dose-dependent rise of absorbance up to a maximum at $50 \mathrm{nM}$, which confirms enhancement of apoptosis by triptolide $(n=6$ per column, mean, $* * * p<0.001$ by Dunnett's multiple comparisons test, controls without DMSO were set 1) (a)
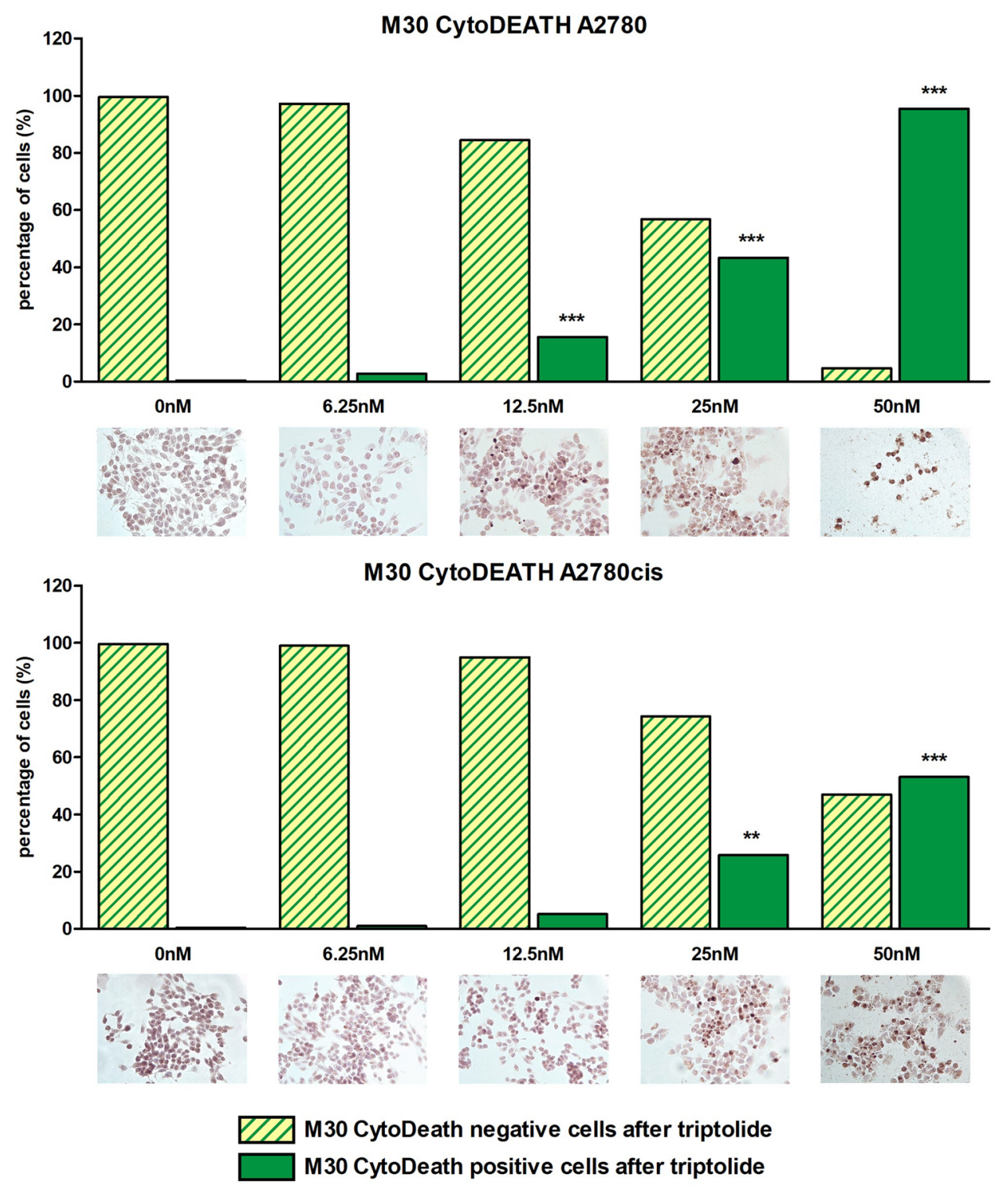

(b)

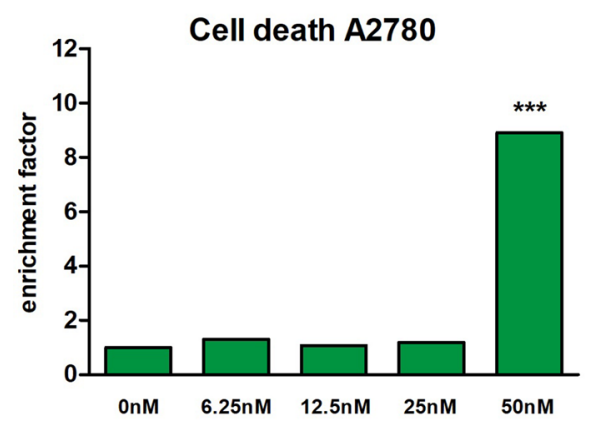

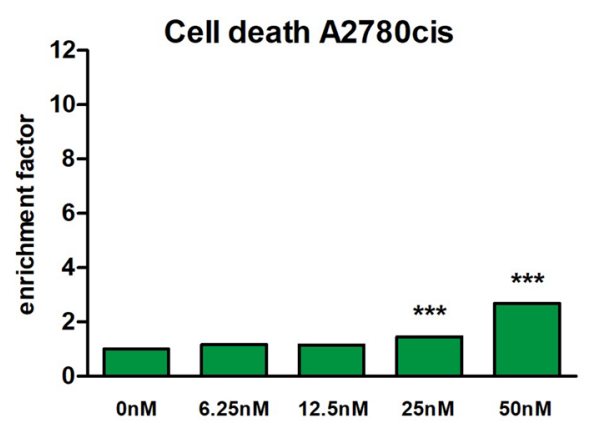


Moreover, histone-associated DNA-fragments, produced as a result of apoptosis, were quantified using a cell death detection ELISA. Incubation for $24 \mathrm{~h}$ with identical triptolide concentrations showed a highly significant $(p<0.001)$ dose-dependent rise of absorbance up to 8.9-times in A2780 and 2.7-times in A2780cis at $50 \mathrm{nM}$ (Fig. 4b), confirming apoptosis' dose-dependence from triptolide in both cell lines.

\section{Cell migration is inhibited by SB216763 and triptolide}

Migration capacity of OC cells was monitored within vitro wound healing assays with $100 \mu \mathrm{M}$ SB216763, $50 \mu \mathrm{M}$ XAV939 or $50 \mathrm{nM}$ triptolide. In A2780, SB216763 and triptolide led to a significant reduction in wound healing after 48 and $72 \mathrm{~h}(p<0.01$ or $p<0.001)$ (Fig. 5a). After $72 \mathrm{~h}$, the remaining wound area for SB216763 was 95.9\% (Fig. 5b) and $59.5 \%$ confluent for triptolide compared to $0.0 \%$ in both controls. Treatment with XAV939 whereas did not affect migration ability in A2780 and A2780cis. In the platinum-resistant cell line, we saw the identical but slightly lower impact of SB216763 (Fig. 5b) and triptolide. Following treatment with $50 \mathrm{nM}$ triptolide after $72 \mathrm{~h}$ the remaining wound area was $37.8 \%$ compared to $3.3 \%$ in the control (Fig. 5a).

(a)
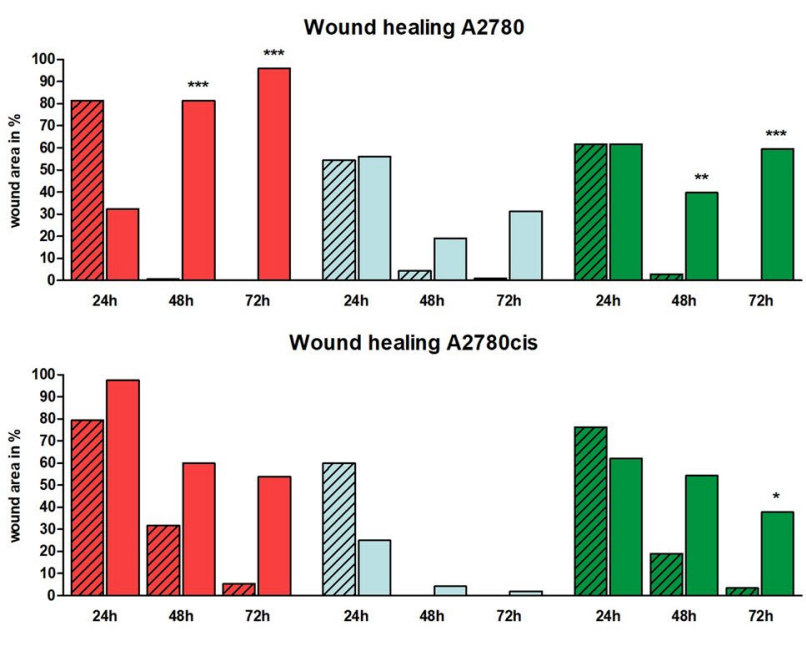

ZZDMSO control $\square$ SB216763 $\square$ XAV939 $\square$ triptolide

Fig. 5 Wound healing assay for different Wnt signaling manipulators in A2780 and A2780cis: a Cell migration in A2780 and A2780cis was significantly reduced through the addition of $100 \mu \mathrm{M} \mathrm{SB} 216763$ or $50 \mathrm{nM}$ triptolide after 48 and $72 \mathrm{~h}$ compared to controls. Treatment with XAV939 did not affect migration ability at all $(n=3$ per column, mean, $* p<0.05 / * * p<0.01 / * * * p<0.001$ by Sidak's multiple com-

\section{Results on human tissue samples}

\section{Markers for Wnt signaling with different expression patterns in serous compared to other subtypes}

To understand the role of Wnt pathway in the clinical context, immunoquantitative comparisons of Wnt signaling markers among four histological subtypes (serous, endometrioid, clear cell, mucinous) were performed. IHC score revealed multiple significant expression differences especially of serous histology compared to other subtypes (Table 3). Membranous and plasmatic B-catenin expression was significantly higher $(p<0.001)$ in endometrioid (membrane: $10.2 \pm 0.4$, plasma: $10.0 \pm 0.4$ ), clear cell (membrane: $10.1 \pm 0.5$, plasma: $10.2 \pm 0.4$ ) and mucinous (membrane: $11.2 \pm 0.4$, plasma: $10.4 \pm 0.8$ ) type compared to serous (membrane: $7.6 \pm 0.2$, plasma: $6.4 \pm 0.2$ ) histology. Moreover, in comparison to serous subtype, expression of plasmatic snail/ slug $(8.8 \pm 0.2)$ and membranous E-cadherin $(7.6 \pm 0.3)$ was significantly lower in endometrioid (snail/ slug: $7.2 \pm 0.5$ [p $<0.05]$, E-cadherin: $4.7 \pm 0.9[p<0.001])$ and clear cell (snail/ slug: $5.4 \pm 0.5[p<0.001]$, E-cadherin: $5.0 \pm 1.0[p<0.05])$ histology. Representative stainings are displayed in Fig. 7b.

(b)
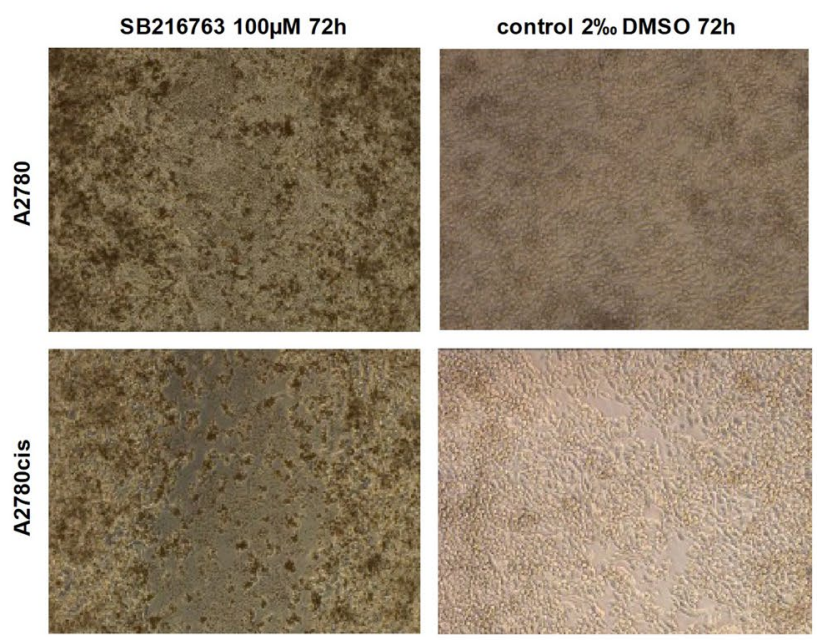

parisons test, wound area after $0 \mathrm{~h}$ was set $100 \%$ ). b Representative images of the wound area in A2780 and A2780cis $72 \mathrm{~h}$ after treatment with $100 \mu \mathrm{M}$ SB216763 compared to controls with 2\%o DMSO. While controls showed a confluent monolayer of cells, in SB216763 treated cells a remaining wound area is visible 
Table 3 Comparison of IHC scores of Wnt signaling markers between histological subtypes: IHC scores in TMAs for $\beta$-catenin, snail/ slug and E-cadherin in different subcellular locations were compared between four different types of EOC (serous [ $n=109]$, endometrioid $[n=21]$, clear cell $[n=11]$, mucinous $[n=12])$

\begin{tabular}{lllllll}
\hline & \multicolumn{2}{l}{ Serous vs. endometrioid } & Serous vs. clear cell & \multicolumn{2}{l}{ Serous vs. mucinous } \\
\hline$\beta$-Catenin (membrane) & $7.6 \pm 0.2$ & $10.2 \pm 0.4$ & $7.6 \pm 0.2$ & $10.1 \pm 0.5$ & $7.6 \pm 0.2$ & $11.2 \pm 0.4$ \\
& $<* * *$ & $<* * *$ & $<* * *$ & $<* * *$ & $<* * *$ & $<* * *$ \\
$\beta$-Catenin (plasma) & $6.4 \pm 0.2$ & $10.0 \pm 0.4$ & $6.4 \pm 0.2$ & $10.2 \pm 0.4$ & $6.4 \pm 0.2$ & $10.4 \pm 0.8$ \\
& $<* * *$ & $<* * *$ & $<* * *$ & $<* * *$ & $<* * *$ & $<* * *$ \\
snail/ slug (plasma) & $8.8 \pm 0.2$ & $7.2 \pm 0.5$ & $8.8 \pm 0.2$ & $5.4 \pm 0.5$ & $8.8 \pm 0.2$ & $6.9 \pm 1.1$ \\
& $>*$ & $>*$ & $>* * *$ & $>* * *$ & n.s & n.s \\
E-Cadherin (membrane) & $7.6 \pm 0.3$ & $4.7 \pm 0.9$ & $7.6 \pm 0.3$ & $5.0 \pm 1.0$ & $7.6 \pm 0.3$ & $7.4 \pm 1.1$ \\
& $>* * *$ & $>* * *$ & $>*$ & $>*$ & n.s & n.s \\
E-Cadherin (plasma) & $7.4 \pm 0.2$ & $8.0 \pm 0.7$ & $7.4 \pm 0.2$ & $5.4 \pm 0.9$ & $7.4 \pm 0.2$ & $8.5 \pm 0.9$ \\
& $\mathrm{n} . \mathrm{s}$ & $\mathrm{n} . \mathrm{s}$ & $>*$ & $>*$ & $\mathrm{n} . \mathrm{s}$ & $\mathrm{n} . \mathrm{s}$ \\
\hline
\end{tabular}

Analysis revealed significant (mean \pm SEM, ${ }^{*} p<0.05 / * * * p<0.001$ by Mann-Whitney- $U$ test) and nonsignificant results (n.s.)

\section{B-catenin and E-cadherin show significant expression differences with regard to FIGO stage}

Comparing expression of Wnt markers with regard to FIGO stage, significantly higher expression of $\beta$-catenin (membrane) $(9.2 \pm 0.4$ to $7.9 \pm 0.2[p<0.01]), \beta$-catenin (plasma) $(8.8 \pm 0.4$ to $6.7 \pm 0.3[p<0.001])$ and E-cadherin (plasma) $(7.7 \pm 0.5$ to $6.8 \pm 0.3[p<0.05])$ were noted for FIGO stage I-II compared to FIGO stage III-IV (Fig. 6).

No significant expression differences were identified for Wnt markers in platinum-resistant compared to platinumsensitive patients (data not shown).

\section{Higher plasmatic snail/ slug expression is associated with significantly longer PFS in serous $O C$}

Prognostic impact of Wnt pathway markers on OS and PFS were tested for the whole cohort and for each subtype. For serous subtype, a significantly longer PFS was noted for higher plasmatic expression of snail/ slug (plasma) expression with a cut-off IHC score of seven or beneath (33.6 \pm 4.8 to $15.6 \pm 2.4$ months [ $p=0.001])$. A similar trend was noted for OS, although this difference did not reach statistical significance $(50.4 \pm 13.2$ to $27.6 \pm 3.6$ months $[p=0.058])$ (Fig. 7).

\section{Discussion}

Development of platinum-resistance is one of the major challenges in the clinical management of EOC. Despite recent advances with the inclusion of targeted therapies to standard treatment as the anti-angiogenic bevacizumab (Burger et al. 2011; Perren et al. 2011) or PARP inhibitors (Coleman et al. 2017; Ledermann et al. 2012, 2014; Mirza et al. 2016; Pujade-Lauraine et al. 2017), no real improvements to overcome resistance to platinum in the clinical course have been achieved so far. Since different studies
Fig. 6 Comparison of IHC scores of Wnt signaling markers dependent on FIGO stages: Analyzing expression of Wnt signaling markers dependent on FIGO stages $(n=153)$ revealed significant differences for $\beta$-catenin and E-cadherin in two different locations (membrane and plasma) (mean \pm SEM, $* p<0.05 / * * p<0.01 /$

$* * * p<0.001$ by Mann-Whitney- $U$ test)

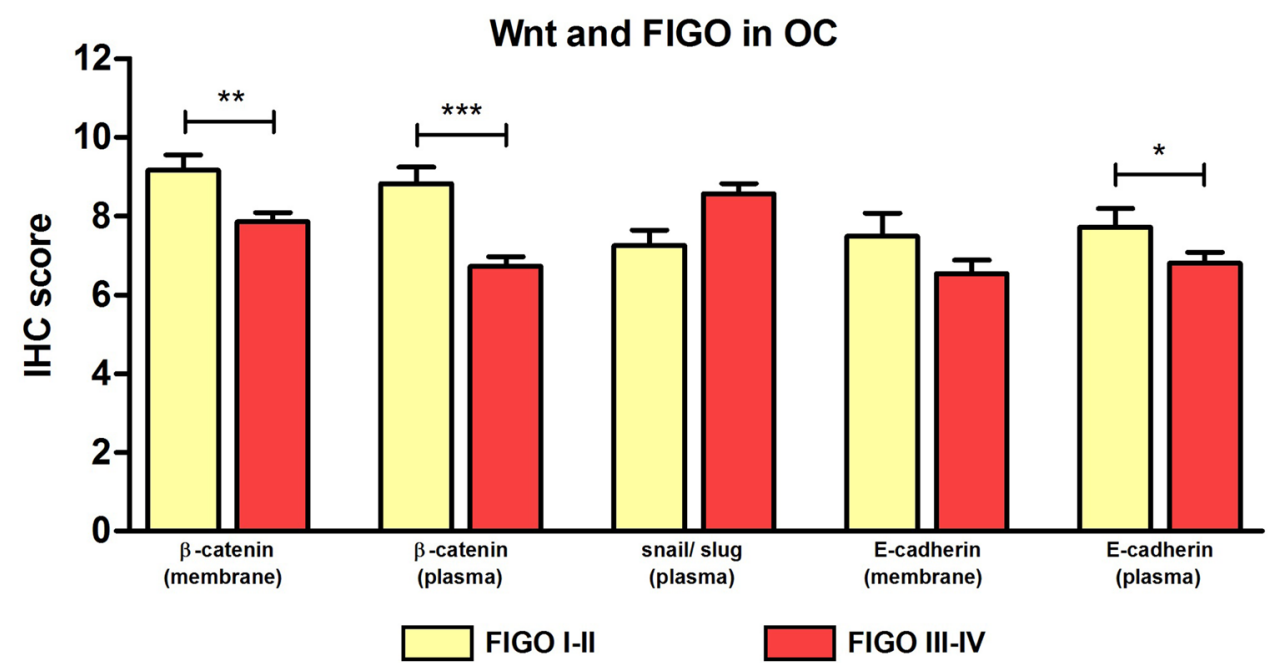


Fig. 7 PFS depending on plasmatic snail/ slug IHC scores in serous EOC and representative microphotographies: a The Kaplan-Meier curves demonstrate PFS and OS as a function of plasmatic snail/slug expression in serous OC cases. Green lines (IHC score $>7$, $\mathrm{PFS}=33.6 \pm 4.8$ months, $\mathrm{OS}=50.4 \pm 13.2$ months) show a significant benefit in PFS and a trend in OS compared to the red line (IHC score $\leq 7$, $\mathrm{PFS}=15.6 \pm 2.4$ months, $\mathrm{OS}=27.6 \pm 3.6$ months $)$ (median \pm SEM, $\mathrm{p}=0.001 /$ $\mathrm{p}=0.058$ by chi-square statistic of the Log-Rank test [MantelCox]). b Plasmatic snail/slug accumulation in serous subtype is marked in brown after DAB treatment. While the left microphotography shows a higher expression (IHC score > 7), on the right photography a lower expression (IHC score $\leq 7$ ) is shown

(a)
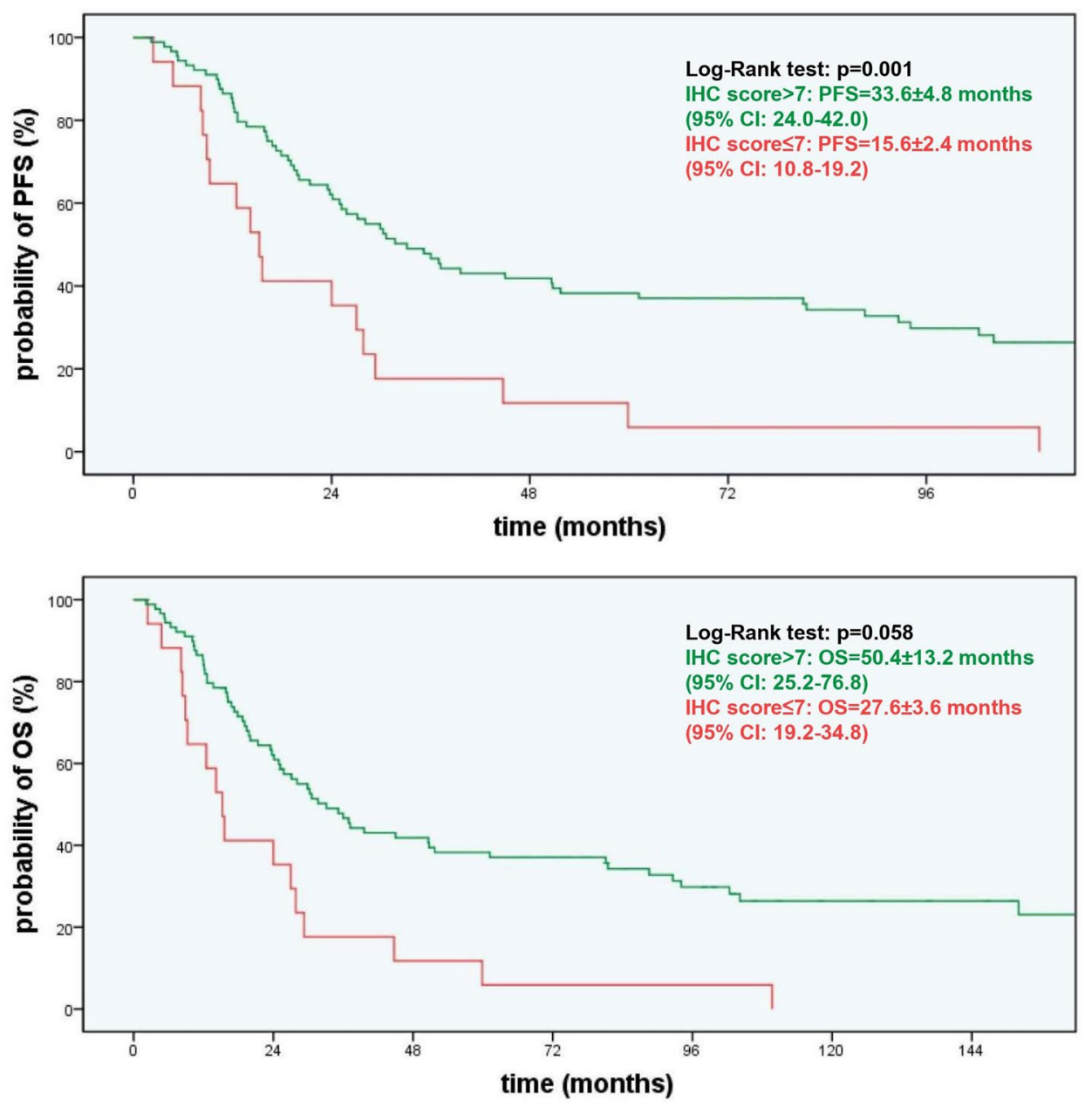

(b)

snail/ slug (plasma) IHC sore $>7$

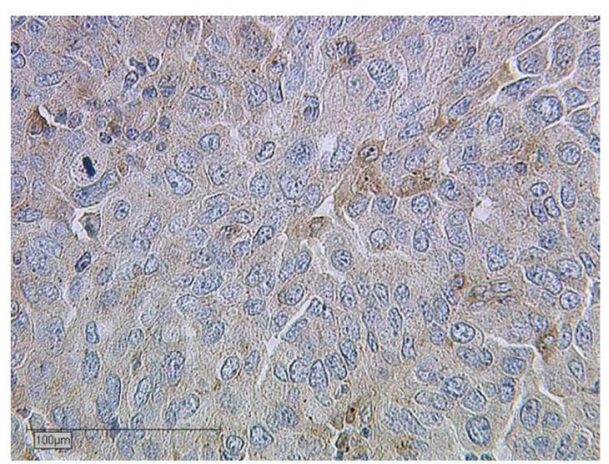

snail/ slug (plasma) IHC sore $\leq 7$

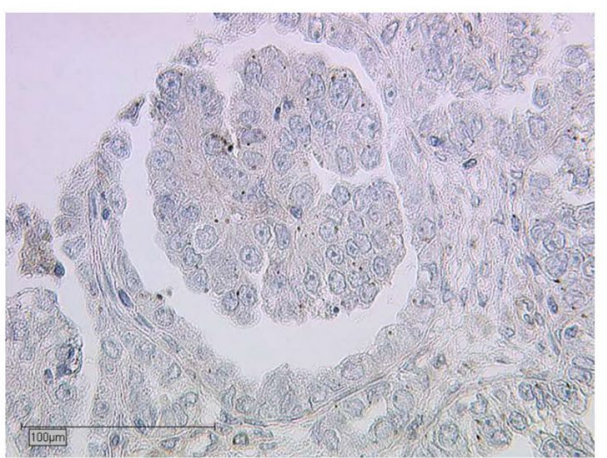

suggest that manipulation of the Wnt pathway may have an impact on tumor progression (Barghout et al. 2015; Boone et al. 2016; Cao et al. 2006; Li et al. 2016; Nagaraj et al. 2015; Rivard et al. 2014; Westfall et al. 2008), we identified three molecules as promising examples for manipulators of the Wnt pathway to investigate the opportunity of resensitization of EOC cells to platinum.

During application of SB216763, XAV939 and triptolide to EOC cell lines A2780 and A2780cis in functional tests in vitro, only triptolide exhibited a continuous effect on cell 
biology with a significant reduction of cell proliferation and cell viability as well as induction of apoptosis. Our results confirm the existing in vitro and in vivo studies in OC cells (Rivard et al. 2014; Westfall et al. 2008): triptolide is able to reduce ovarian tumor cell progress applied as a single agent or compared with carboplatin. But in contrast to earlier studies, we directly used triptolide but no prodrug.

The inhibitor of canonical Wnt signaling XAV939 led to significantly impaired cell viability matching with a study from $\mathrm{Li}$ et al., in which the importance of long non-coding RNA HOTAIR for Wnt signaling driven chemoresistence of OC cells was demonstrated and XAV939 was able to partially block this effect ( $\mathrm{Li}$ et al. 2016). Furthermore, in colorectal cancer cells XAV939 significantly increased the apoptotic cell fraction alone or in combination with 5-fluorouracil and cisplatin (Wu et al. 2016). Indeed, experiments on XAV939's direct impact on both platinum-resistant and -sensitive EOC cells were missing by now, as well as for SB216763.

Interestingly, treatment with this GSK-3 $\beta$ inhibitor and thus Wnt activator presented similar results as for XAV939 treatment. In addition, SB216763 treatment resulted in a significant reduction of cell proliferation in A2780cis. Our results are consistent with the work of Cao et al. and Schulz et al., who detected GSK-3 $\beta$ as a driving force in tumor cell progression in EOC (Cao et al. 2006) and squamous cell carcinomas of the head and neck (Schulz et al. 2018). These results confirm that GSK-3 $\beta$ necessarily influences functional tests on EOC cells via other pathways besides Wnt, like a NF-kB-dependent pathway (Ougolkov et al. 2005) or a modulation by the tumor microenvironment (Fridman et al. 2014; Giraldo et al. 2019). Furthermore, the diversity of Wnt's target gene panel (Arend et al. 2013; Talbot et al. 2012) also offers options for inhibitory functions of Wnt in tumor progression.

Another finding of this study was the ability of all three drugs tested, to inhibit cell migration. Significance was seen for triptolide in both cell lines as well as for SB216763 in A2780. Epithelial-mesenchymal transition (EMT) is a key mechanism in cell migration and Wnt signaling is one of EMT's major pathways (Talbot et al. 2012). In OC, the inhibition of EMT by treatment with a Wnt repressor (salinomycin) has been proved already (Li et al. 2017), but to our knowledge this is the first data set on a platinum-resistant cell line. Concordant with the putative bipolarity of GSK-3 $\beta$ in tumor biology, results on the transcriptional profile of various EMT related genes in response to SB216763 were summarized as a dysregulated EMT without any clear direction by the authors of this study (Schulz et al. 2018).

Summarizing the functional tests mentioned above SB216763, XAV939 and triptolide effect both platinum-sensitive and -resistant cells. The results provide the opportunity to potentiate the impact of a platinum-based chemotherapy but were not able to show a fully resensitization of EOC cells to carboplatin. This confirms findings on other Wnt inhibitors in OC (Barghout et al. 2015; Boone et al. 2016; Nagaraj et al. 2015; Rivard et al. 2014; Westfall et al. 2008) and opens promising perspectives for clinical management of platinum-resistant patients.

Of course, varieties in significance levels throughout the functional tests are a limitation of this study and most likely caused by relatively small sample sizes. Nevertheless, this was not the primary aim of our work and needs further examinations. Moreover, the cell line A2780 mainly represents features of the endometrioid subtype (Anglesio et al. 2013; Köbel et al. 2008) and is thus not able to act as a reliable model for all histological subtypes of EOC. However, especially in OC research it is a well-established cell model, representing the typical contrast of platinum-resistant and -sensible cells.

To improve the understanding of Wnt signaling's diverse role in OC progress, we aimed to detect the localization of $\beta$-catenin (membrane versus nucleus) after SB216763 or XAV939 treatment in both cell lines. In parallel to the functional tests, both drugs led to an immunohistochemical shift of $\beta$-catenin from the nucleus (Wnt signaling activated) to the membrane (Wnt signaling inactivated), which finally contrasts the general role of SB216763 as an activator of the pathway (Naujok et al. 2014). Our results are in line with a diverse role of GSK-3 $\beta$ in cancer's context (Patel and Woodgett 2008) and may support a general dysregulation of Wnt and EMT in some cancers (Schulz et al. 2018). Certainly, the phosphorylation pattern is one approach to explain this bipolarity. In general, the kinase is inactivated through phosphorylation at serine residue nine (GSK-3 $\beta[\mathrm{pS} 9]$ ) or activated through phosphorylation at tyrosine residue 216 (GSK-3ß[pY216]) (Domoto et al. 2016; Fang et al. 2002). Paradoxically, a completely deregulated activity of GSK-3 $\beta$ according to modifications in the differential phosphorylation of S9 and Y216 residues was seen in gastrointestinal cancers (Mai et al. 2009) and glioblastoma (Miyashita et al. 2009) compared to "healthy" cells. The present results support this thesis in $\mathrm{OC}$ for the first time.

To correlate the in vivo examinations with the impact of Wnt marker proteins on the clinical course of OC, a homogenously treated cohort of formalin-fixed paraffin-embedded tissue from EOC patients was examined. In a comparison between the histologic subtypes, the serous subtype is usually thought to have the highest activity of Wnt signaling (Lee et al. 2003), as it is dominated by the high-grade carcinomas with their poor prognosis (Jayson et al. 2014; Köbel et al. 2008). Our study supports this observation, since the small fraction of extranuclear $\beta$-catenin in serous subtype compared to the others as well as in FIGO stage III-IV compared to FIGO stage I-II. 
E-cadherin, a molecule mediating cell-cell adhesion, is usually regarded as an invasion suppressor. However, especially EOC cells additionally undergo a mesenchymal-epithelial transition. Thus, in contrast to other cancers (Berx and van Roy 2009), E-cadherin is mostly elevated. The higher E-cadherin expression in lower stages could be confirmed as previously described (Arend et al. 2013; Bodnar et al. 2014), but we detected a significant difference in E-cadherin expression between the different subtypes.

Snail/ slug is a transcription factor, localized in the plasma of the cell when Wnt signaling is inactivated (Kim et al. 2012). Interestingly, it is the only Wnt marker tested with a clear correlation to PFS or OS: in our study an elevated expression of snail/ slug in the serous subtype is significantly associated with longer PFS and shows a positive trend for OS. The transcription factor snail/ slug is wellknown for its tumor-promoting influence as a driver in EMT. Induced autophagy of this protein led to control of EMT and metastasis in a HeLa cell model (Zada et al. 2019) and knockdown of it suppresses ovarian tumor growth (Baldwin et al. 2014). In lung carcinoma cells this positive influence on tumor progress was clearly correlated to translocation into the nucleus (Perumal et al. 2019). Since current scientific data for snail/ slug's role are homogenous among each other and with our results, inhibition of snail/ slug or at least persistent shift towards plasma might be a promising base for prognostic approaches in the future.

\section{Conclusion}

Functional tests investigating the impact of the Wnt manipulators SB216763, XAV939 and triptolide on the OC cell lines A2780 and A2780cis detected significant effects on both platinum-sensitive and -resistant cells. With this, all three manipulators provide the opportunity to emphasize the impact of a platinum-based chemotherapy. While specific results of the substances were heterogenous, the inhibitory impact of triptolide itself on OC tumor progression and its promoting impact on apoptosis has to be highlighted. Repression of EMT markers by Wnt inhibition was shown for the first time in the context of platinum-resistant OC cell lines. Our analysis on the existing EOC patient cohort confirmed a potential role of the Wnt pathway in serous OC cases, which is of note as it is the most common histological subgroup of OC. Together with the different expression levels of $\beta$-catenin and E-cadherin between FIGO stages and the impact of the expression levels for snail/ slug on prognosis, this study enables perspectives for clinical management of platinum-resistant patients through manipulation of the Wnt/ $\beta$-catenin pathway.
Acknowledgements Open Access funding provided by Projekt DEAL. We thank Christina Kuhn and Martina Rahmeh for excellent technical assistance.

Author contributions Conceptualization: Till Kaltofen, Udo Jeschke, Sven Mahner and Fabian Trillsch; Methodology: Udo Jeschke and Fabian Trillsch; Investigation and formal analysis: Till Kaltofen, Valentina Preinfalk, Stephanie Schwertler, Patricia Fraungruber, Helene Heidegger, Theresa Vilsmaier, Aurelia Vattai and Bastian Czogalla; Pathological examination: Doris Mayr; Writing and original draft preparation: Till Kaltofen; Review and editing: Udo Jeschke, Sven Mahner and Fabian Trillsch; Supervision: Udo Jeschke and Fabian Trillsch. All authors analyzed and interpreted the data and read and approved the final manuscript.

Funding This research was funded by the LMU Munich Medical Faculty. We acknowledge financial support by the Friedrich-Baur-Stiftung (registration number 33/19) for Till Kaltofen.

Availability of data and material The datasets generated and analysed during the current study are available from the corresponding author on reasonable request.

\section{Compliance with ethical standard}

Conflict of interest Sven Mahner reports grants and personal fees from AstraZeneca, Clovis, Medac, MSD, PharmaMar, Roche, Sensor Kinesis, Tesaro and Teva outside the submitted work. Fabian Trillsch has received grants and personal fees from AstraZeneca, Clovis, Medac, PharmaMar, Roche and Tesaro outside the submitted work. The other authors declare no conflict of interest.

Ethics approval All procedures performed in studies involving human participants were in accordance with the ethical standards of the institutional research committee and with the 1964 Helsinki Declaration (last revision October 2018) and its later amendments or comparable ethical standards. The study was approved by the bioethics committee of Ludwig Maximilian University of Munich (number 138/03).

Consent to participate Informed consent was obtained for the specimens from all individual participants included in the study.

Open Access This article is licensed under a Creative Commons Attribution 4.0 International License, which permits use, sharing, adaptation, distribution and reproduction in any medium or format, as long as you give appropriate credit to the original author(s) and the source, provide a link to the Creative Commons licence, and indicate if changes were made. The images or other third party material in this article are included in the article's Creative Commons licence, unless indicated otherwise in a credit line to the material. If material is not included in the article's Creative Commons licence and your intended use is not permitted by statutory regulation or exceeds the permitted use, you will need to obtain permission directly from the copyright holder. To view a copy of this licence, visit http://creativecommons.org/licenses/by/4.0/.

\section{References}

Anglesio MS, Wiegand KC, Melnyk N, Chow C, Salamanca C, Prentice LM, Senz J, Yang W, Spillman MA, Cochrane DR, Shumansky K, Shah SP, Kalloger SE, Huntsman DG (2013) Type-specific 
cell line models for type-specific ovarian cancer research. PLoS ONE 8:e72162. https://doi.org/10.1371/journal.pone.0072162

Arend RC, Londoño-Joshi AI, Straughn JM Jr, Buchsbaum DJ (2013) The Wnt/ $\beta$-catenin pathway in ovarian cancer: A review. Gynecol Oncol 131:772-779. https://doi.org/10.1016/j.ygyno.2013.09.034

Baldwin LA, Hoff JT, Lefringhouse J, Zhang M, Jia C, Liu Z, Erfani S, Jin H, Xu M, She Q-B, van Nagell JR, Wang C, Chen L, Plattner R, Kaetzel DM, Luo J, Lu M, West D, Liu C, Ueland FR, Drapkin R, Zhou BP, Yang XH (2014) CD151- $\alpha 3 \beta 1$ integrin complexes suppress ovarian tumor growth by repressing slug-mediated EMT and canonical Wnt signaling. Oncotarget 5:12203-12217. https:// doi.org/10.18632/oncotarget.2622

Barghout SH, Zepeda N, Xu Z, Steed H, Lee C-H, Fu Y (2015) Elevated $\beta$-catenin activity contributes to carboplatin resistance in A2780cp ovarian cancer cells. Biochem Biophys Res Commun 468:173-178. https://doi.org/10.1016/j.bbrc.2015.10.138

Berx G, van Roy F (2009) Involvement of members of the cadherin superfamily in cancer. Cold Spring Harb Perspect Biol 1:a003129. https://doi.org/10.1101/cshperspect.a003129

Bodnar L, Stanczak A, Cierniak S, Smoter M, Cichowicz M, Kozlowski W, Szczylik C, Wieczorek M, Lamparska-Przybysz M (2014) $\mathrm{Wnt} / \beta$-catenin pathway as a potential prognostic and predictive marker in patients with advanced ovarian cancer. J Ovarian Res 7:16. https://doi.org/10.1186/1757-2215-7-16

Boone JD, Arend RC, Johnston BE, Cooper SJ, Gilchrist SA, Oelschlager DK, Grizzle WE, McGwin G, Gangrade A, Straughn JM, Buchsbaum DJ (2016) Targeting the Wnt/ $\beta$-catenin pathway in primary ovarian cancer with the porcupine inhibitor WNT974. Lab Invest 96:249-259. https://doi.org/10.1038/labin vest. 2015.150

Burger RA, Brady MF, Bookman MA, Fleming GF, Monk BJ, Huang H, Mannel RS, Homesley HD, Fowler J, Greer BE, Boente M, Birrer MJ, Liang SX (2011) Incorporation of Bevacizumab in the Primary Treatment of Ovarian Cancer. N Engl J Med 365:24732483. https://doi.org/10.1056/NEJMoa1104390

Cao Q, Lu X, Feng Y-J (2006) Glycogen synthase kinase-3ß positively regulates the proliferation of human ovarian cancer cells. Cell Res 16:671-677. https://doi.org/10.1038/sj.cr.7310078

Chen B, Dodge ME, Tang W, Lu J, Ma Z, Fan C-W, Wei S, Hao W, Kilgore J, Williams NS, Roth MG, Amatruda JF, Chen C, Lum L (2009) Small molecule-mediated disruption of Wnt-dependent signaling in tissue regeneration and cancer. Nat Chem Biol 5:100107. https://doi.org/10.1038/nchembio. 137

Coleman RL, Oza AM, Lorusso D, Aghajanian C, Oaknin A, Dean A, Colombo N, Weberpals JI, Clamp A, Scambia G, Leary A, Holloway RW, Gancedo MA, Fong PC, Goh JC, O'Malley DM, Armstrong DK, Garcia-Donas J, Swisher EM, Floquet A, Konecny GE, McNeish IA, Scott CL, Cameron T, Maloney L, Isaacson J, Goble S, Grace C, Harding TC, Raponi M, Sun J, Lin KK, Giordano H, Ledermann JA, Buck M, Dean A, Friedlander ML, Goh JC, Harnett P, Kichenadasse G, Scott CL, Denys H, Dirix L, Vergote I, Elit L, Ghatage P, Oza AM, Plante M, Provencher D, Weberpals JI, Welch S, Floquet A, Gladieff L, Joly F, Leary A, Lortholary A, Lotz J, Medioni J, Tredan O, You B, El-Balat A, Hänle C, Krabisch P, Neunhöffer T, Pölcher M, Wimberger P, Amit A, Kovel S, Leviov M, Safra T, Shapira-Frommer R, Stemmer S, Bologna A, Colombo N, Lorusso D, Pignata S, Sabbatini RF, Scambia G, Tamberi S, Zamagni C, Fong PC, O'Donnell A, Gancedo MA, Herraez AC, Garcia-Donas J, Guerra EM, Oaknin A, Palacio I, Romero I, Sanchez A, Banerjee SN, Clamp A, Drew Y, Gabra HG, Jackson D, Ledermann JA, McNeish IA, Parkinson C, Powell M, Aghajanian C, Armstrong DK, Birrer MJ, Buss MK, Chambers SK, Chen L-m, Coleman RL, Holloway RW, Konecny GE, Ma L, Morgan MA, Morris RT, Mutch DG, O'Malley DM, Slomovitz BM, Swisher EM, Vanderkwaak T, Vulfovich M (2017) Rucaparib maintenance treatment for recurrent ovarian carcinoma after response to platinum therapy (ARIEL3): a randomised, double-blind, placebo-controlled, phase 3 trial. Lancet 390:1949-1961. https://doi.org/10.1016/S0140-6736(17)32440-6

Domoto T, Pyko IV, Furuta T, Miyashita K, Uehara M, Shimasaki T, Nakada M, Minamoto T (2016) Glycogen synthase kinase-3 $\beta$ is a pivotal mediator of cancer invasion and resistance to therapy. Cancer Sci 107:1363-1372. https://doi.org/10.1111/cas.13028

Dubeau L (2008) The cell of origin of ovarian epithelial tumours. Lancet Oncol 9:1191-1197. https://doi.org/10.1016/j.ygyno .2013.09.034

Fang X, Yu S, Tanyi JL, Lu Y, Woodgett JR, Mills GB (2002) Convergence of Multiple Signaling Cascades at Glycogen Synthase Kinase 3: Edg Receptor-Mediated Phosphorylation and Inactivation by Lysophosphatidic Acid through a Protein Kinase C-Dependent Intracellular Pathway. Mol Cell Biol 22:2099-2110. https://doi.org/10.1128/mcb.22.7.2099-2110.2002

Freimund AE, Beach JA, Christie EL, Bowtell DDL (2018) Mechanisms of Drug Resistance in High-Grade Serous Ovarian Cancer. Hematol Oncol Clin North Am 32:983-996. https://doi. org/10.1016/j.hoc.2018.07.007

Fridman WH, Remark R, Goc J, Giraldo NA, Becht E, Hammond SA, Damotte D, Dieu-Nosjean MC, Sautès-Fridman C (2014) The immune microenvironment: A major player in human cancers. Int Arch Allergy Immunol 164:13-26. https://doi. org $/ 10.1159 / 000362332$

Gasior K, Hauck M, Wilson A, Bhattacharya S (2017) A Theoretical Model of the Wnt Signaling Pathway in the Epithelial Mesenchymal Transition. Theor Biol Med Model 14:19. https://doi. org/10.1186/s12976-017-0064-7

Gatcliffe TA, Monk BJ, Planutis K, Holcombe RF (2008) Wnt signaling in ovarian tumorigenesis. Int J Gynecol Cancer 18:954-962. https://doi.org/10.1111/j.1525-1438.2007.01127.x

Geiger P, Mayer B, Wiest I, Schulze S, Jeschke U, Weissenbacher $\mathrm{T}$ (2016) Binding of galectin-1 to breast cancer cells MCF7 induces apoptosis and inhibition of proliferation in vitro in a 2D- and 3D- cell culture model. BMC Cancer 16:870. https:// doi.org/10.1186/s12885-016-2915-8

Giraldo NA, Sanchez-Salas R, Peske JD, Vano Y, Becht E, Petitprez F, Validire $\mathrm{P}$, Ingels A, Cathelineau X, Fridman WH, Sautès-Fridman C (2019) The clinical role of the TME in solid cancer. Br J Cancer 120:45-53. https://doi.org/10.1038/s4141 6-018-0327-z

International Agency for Research on Cancer (2020) World Cancer Report: Cancer Research for Cancer Prevention, Lyon, pp 411-420

Jayson GC, Kohn EC, Kitchener HC, Ledermann JA (2014) Ovarian cancer. Lancet 384:1376-1388. https://doi.org/10.1016/S0140 -6736(13)62146-7

Kim H, Wu R, Cho KR, Thomas DG, Gossner G, Liu JR, Giordano TJ, Shedden KA, Misek DE, Lubman DM (2008) Comparative proteomic analysis of low stage and high stage endometrioid ovarian adenocarcinomas. Proteomics Clin Appl 2:571-584. https://doi. org/10.1002/prca.200780004

Kim JY, Kim YM, Yang CH, Cho SK, Lee JW, Cho M (2012) Functional regulation of Slug/Snail2 is dependent on GSK-3 $\beta$-mediated phosphorylation. FEBS J 279:2929-2939. https://doi.org/10.111 1/j.1742-4658.2012.08674.x

Köbel M, Kalloger SE, Boyd N, McKinney S, Mehl E, Palmer C, Leung S, Bowen NJ, Ionescu DN, Rajput A, Prentice LM, Miller D, Santos J, Senerton K, Gilks CB, Huntsman D (2008) Ovarian Carcinoma Subtypes Are Different Diseases: Implications for Biomarker Studies. PLoS Med 5:e232. https://doi.org/10.1371/ journal.pmed.0050232

Ledermann J, Harter P, Gourley C, Friedlander M, Vergote I, Rustin G, Scott C, Meier W, Shapira-Frommer R, Safra T, Matei D, Macpherson E, Watkins C, Carmichael J, Matulonis U (2012) 
Olaparib Maintenance Therapy in Platinum-Sensitive Relapsed Ovarian Cancer. N Engl J Med 366:1382-1392. https://doi. org/10.1056/NEJMoa1105535

Ledermann J, Harter P, Gourley C, Friedlander M, Vergote I, Rustin G, Scott CL, Meier W, Shapira-Frommer R, Safra T, Matei D, Fielding A, Spencer S, Dougherty B, Orr M, Hodgson D, Barrett JC, Matulonis U (2014) Olaparib maintenance therapy in patients with platinum-sensitive relapsed serous ovarian cancer: A preplanned retrospective analysis of outcomes by BRCA status in a randomised phase 2 trial. Lancet Oncol 15:852-861. https://doi. org/10.1016/S1470-2045(14)70228-1

Lee CM, Shvartsman H, Deavers MT, Wang S-C, Xia W, Schmandt R, Bodurka DC, Atkinson EN, Malpica A, Gershenson DM, Hung M-C, Lu KH (2003) $\beta$-catenin nuclear localization is associated with grade in ovarian serous carcinoma. Gynecol Oncol 88:363368. https://doi.org/10.1016/S0090-8258(02)00015-X

Li J, Yang S, Su N, Wang Y, Yu J, Qiu H, He X (2016) Overexpression of long non-coding RNA HOTAIR leads to chemoresistance by activating the $\mathrm{Wnt} / \beta$-catenin pathway in human ovarian cancer. Tumour Biol 37:2057-2065. https://doi.org/10.1007/s1327 7-015-3998-6

Li R, Dong T, Hu C, Lu J, Dai J, Liu P (2017) Salinomycin repressed the epithelial-mesenchymal transition of epithelial ovarian cancer cells via downregulating Wnt/ $\beta$-catenin pathway. Onco Targets Ther 10:1317-1325. https://doi.org/10.2147/OTT.S126463

Mai W, Kawakami K, Shakoori A, Kyo S, Miyashita K, Yokoi K, Jin M, Shimasaki T, Motoo Y, Minamoto T (2009) Deregulated GSK3\{beta\} Sustains Gastrointestinal Cancer Cells Survival by Modulating Human Telomerase Reverse Transcriptase and Telomerase. Clin Cancer Res 15:6810-6819. https://doi. org/10.1158/1078-0432.CCR-09-0973

Mirza MR, Monk BJ, Herrstedt J, Oza AM, Mahner S, Redondo A, Fabbro M, Ledermann JA, Lorusso D, Vergote I, Ben-Baruch NE, Marth C, Mądry R, Christensen RD, Berek JS, Dørum A, Tinker AV, du Bois A, González-Martín A, Follana P, Benigno B, Rosenberg P, Gilbert L, Rimel BJ, Buscema J, Balser JP, Agarwal S, Matulonis UA (2016) Niraparib Maintenance Therapy in Platinum-Sensitive, Recurrent Ovarian Cancer. N Engl J Med 375:2154-2164. https://doi.org/10.1056/NEJMoa1611310

Miyashita K, Kawakami K, Nakada M, Mai W, Shakoori A, Fujisawa H, Hayashi Y, Hamada J-i, Minamoto T (2009) Potential therapeutic effect of glycogen synthase kinase 3beta inhibition against human glioblastoma. Clin Cancer Res 15:887-897. https://doi. org/10.1158/1078-0432.CCR-08-0760

Nagaraj AB, Joseph P, Kovalenko O, Singh S, Armstrong A, Redline R, Resnick K, Zanotti K, Waggoner S, DiFeo A (2015) Critical role of Wnt/ $\beta$-catenin signaling in driving epithelial ovarian cancer platinum resistance. Oncotarget 6:23720-23734. https://doi. org/10.18632/oncotarget.4690

Naujok O, Lentes J, Diekmann U, Davenport C, Lenzen S (2014) Cytotoxicity and activation of the $\mathrm{Wnt} /$ beta-catenin pathway in mouse embryonic stem cells treated with four GSK3 inhibitors. BMC Res Notes 7:273. https://doi.org/10.1186/1756-0500-7-273

Nusse R, Clevers H (2017) Wnt/ $\beta$-Catenin Signaling, Disease, and Emerging Therapeutic Modalities. Cell 169:985-999. https://doi. org/10.1016/j.cell.2017.05.016

Ougolkov AV, Fernandez-Zapico ME, Savoy DN, Urrutia RA, Billadeau DD (2005) Glycogen Synthase Kinase-3B Participates in Nuclear Factor KB-Mediated Gene Transcription and Cell Survival in Pancreatic Cancer Cells. Cancer Res 65:2067-2081. https ://doi.org/10.1158/0008-5472.CAN-04-3642

Patel S, Woodgett J (2008) Glycogen synthase kinase-3 and cancer: Good cop, bad cop? Cancer Cell 14:351-353. https://doi. org/10.1016/j.ccr.2008.10.013

Perren TJ, Swart AM, Pfisterer J, Ledermann JA, Pujade-Lauraine E, Kristensen G, Carey MS, Beale P, Cervantes A, Kurzeder C, du
Bois A, Sehouli Jalid J, Kimmig Rainer R, Stähle A, Collinson F, Essapen S, Gourley C, Lortholary A, Selle F, Mirza MR, Leminen A, Plante M, Stark D, Qian W, Parmar MKB, Oza AM (2011) 365 A Phase 3 Trial of Bevacizumab in Ovarian Cancer. N Engl J Med 2011:2484-2496. https://doi.org/10.1056/NEJMoa1103799

Perumal E, So Youn K, Sun S, Seung-Hyun J, Suji M, Jieying L, YeunJun C (2019) PTEN inactivation induces epithelial-mesenchymal transition and metastasis by intranuclear translocation of $\beta$-catenin and snail/slug in non-small cell lung carcinoma cells. Lung Cancer 130:25-34. https://doi.org/10.1016/j.lungcan.2019.01.013

Pujade-Lauraine E, Ledermann JA, Selle F, Gebski V, Penson RT, Oza AM, Korach J, Huzarski T, Poveda A, Pignata S, Friedlander M, Colombo N, Harter P, Fujiwara K, Ray-Coquard I, Banerjee S, Liu J, Lowe ES, Bloomfield R, Pautier P, Byrski T, Scambia G, Nicoletto M, Nussey F, Clamp A, Penson R, Oza A, Poveda Velasco A, Rodrigues M, Lotz J-P, Provencher D, Prat Aparicio A, Vidal Boixader L, Scott C, Tamura K, Yunokawa M, Lisyanskaya A, Medioni J, Pécuchet N, Dubot C, La Motte RT, Kaminsky M-C, Weber B, Lortholary A, Parkinson C, Ledermann J, Williams S, Cosin J, Hoffman J, Plante M, Covens A, Sonke G, Joly F, Floquet A, Hirte H, Amit A, Park-Simon T-W, Matsumoto K, Tjulandin S, Kim JH, Gladieff L, Sabbatini R, O’Malley D, Timmins P, Kredentser D, Laínez Milagro N, Barretina Ginesta MP, Tibau Martorell A, de Liaño G, Lista A, Ojeda González B, Mileshkin L, Mandai M, Boere I, Ottevanger P, Nam J-H, Filho E, Hamizi S, Cognetti F, Warshal D, Dickson-Michelson E, Kamelle S, McKenzie N, Rodriguez G, Armstrong D, Chalas E, Celano P, Behbakht K, Davidson S, Welch S, Helpman L, Fishman A, Bruchim I, Sikorska M, Słowińska A, Rogowski W, Bidziński M, Śpiewankiewicz B, Casado Herraez A, Mendiola Fernández C, Gropp-Meier M, Saito T, Takehara K, Enomoto T, Watari H, Choi CH, Kim B-G, Kim JW, Hegg R, Vergote I (2017) Olaparib tablets as maintenance therapy in patients with platinum-sensitive, relapsed ovarian cancer and a BRCA1/2 mutation (SOLO2/ENGOTOv21): a double-blind, randomised, placebo-controlled, phase 3 trial. Lancet Oncol 18:1274-1284. https://doi.org/10.1016/ S1470-2045(17)30469-2

Rabik CA, Dolan ME (2007) Molecular Mechanisms of Resistance and Toxicity Associated with Platinating Agents. Cancer Treat Rev 33:9-23. https://doi.org/10.1016/j.ctrv.2006.09.006

Remmele W, Stegner HE (1987) Recommendation for uniform definition of an immunoreactive score (IRS) for immunohistochemical estrogen receptor detection (ER-ICA) in breast cancer tissue. Pathologe 8:138-140

Rivard C, Geller M, Schnettler E, Saluja M, Vogel RI, Saluja A, Ramakrishnan S (2014) Inhibition of epithelial ovarian cancer by Minnelide, a water-soluble pro-drug. Gynecol Oncol 135:318-324. https://doi.org/10.1016/j.ygyno.2014.08.031

Scholz C, Heublein S, Lenhard M, Friese K, Mayr D, Jeschke U (2012) Glycodelin A is a prognostic marker to predict poor outcome in advanced stage ovarian cancer patients. BMC Res Notes 5:551. https://doi.org/10.1186/1756-0500-5-551

Schulz L, Pries R, Lanka AS, Drenckhan M, Rades D, Wollenberg B (2018) Inhibition of GSK3 $\alpha / \beta$ impairs the progression of HNSCC. Oncotarget 9:27630-27644. https://doi.org/10.18632 /oncotarget. 25250

Seagle B-LL, Dandapani M, Yeh JY, Shahabi S (2016) Wnt Signaling and Survival of Women With High-Grade Serous Ovarian Cancer: A Brief Report. Int J Gynecol Cancer 26:1078-1080. https://doi.org/10.1097/IGC.0000000000000726

Shang S, Hua F, Hu Z-W (2017) The regulation of $\beta$-catenin activity and function in cancer: therapeutic opportunities. Oncotarget 8:33972-33989. https://doi.org/10.18632/oncotarget.15687

Shao H, Ma J, Guo T, Hu R (2014) Triptolide induces apoptosis of breast cancer cells via a mechanism associated with the 
Wnt/ $\beta$-catenin signaling pathway. Exp Ther Med 8:505-508. https://doi.org/10.3892/etm.2014.1729

Talbot LJ, Bhattacharya SD, Kuo PC (2012) Epithelial-mesenchymal transition, the tumor microenvironment, and metastatic behavior of epithelial malignancies. Int J Biochem Mol Biol 3:117-136

Westfall SD, Nilsson EE, Skinner MK (2008) Role of Triptolide as an Adjunct Chemotherapy for Ovarian Cancer. Chemotherapy 54:67-76. https://doi.org/10.1159/000112419

Wiese KE, Nusse R, van Amerongen R (2018) Wnt signalling: conquering complexity. Development. https://doi.org/10.1242/ dev. 165902

Wu X, Luo F, Li J, Zhong X, Liu K (2016) Tankyrase 1 inhibitior XAV939 increases chemosensitivity in colon cancer cell lines via inhibition of the Wnt signaling pathway. Int J Oncol 48:1333-1340. https://doi.org/10.3892/ijo.2016.3360
Yang S, Chen J, Guo Z, Xu X-M, Wang L, Pei X-F, Yang J, Underhill CB, Zhang L (2003) Triptolide Inhibits the Growth and Metastasis of Solid Tumors. Mol Cancer Ther 2:65-72

Zada S, Hwang JS, Ahmed M, Lai TH, Pham TM, Kim DR (2019) Control of the Epithelial-to-Mesenchymal Transition and Cancer Metastasis by Autophagy-Dependent SNAI1 Degradation. Cells 8:e129. https://doi.org/10.3390/cells8020129

Zhu J, Trillsch F, Mayr D, Kuhn C, Rameh M, Hofmann S, Vogel M, Mahner S, Jeschke U, Viktoria vS (2018) Prostaglandin receptor EP3 regulates cell proliferation and migration with impact on survival of endometrial cancer patients. Oncotarget 9:982-994. https://doi.org/10.18632/oncotarget.23140

Publisher's Note Springer Nature remains neutral with regard to jurisdictional claims in published maps and institutional affiliations. 